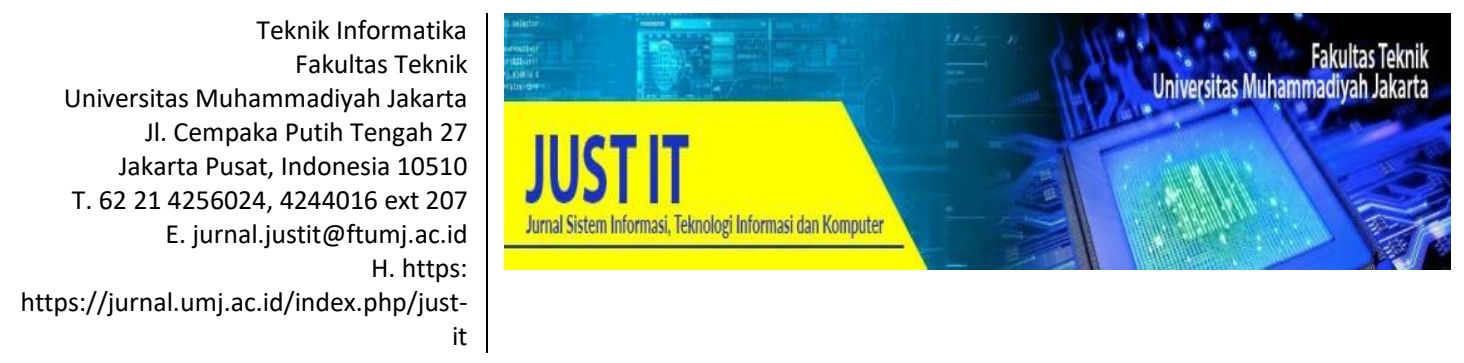

\title{
SISTEM PENDUKUNG KEPUTUSAN DALAM MENENTUKAN PEMILIHAN POSISI KEPALA UNIT (KANIT) PPA DENGAN METODE WEIGHT PRODUCT
}

\author{
Sumarno' $^{1}$, Jauhari Mustafa Harahap ${ }^{2}$ \\ ${ }^{1,2}$ STIKOM Tunas Bangsa. Jalan Jenderal Sudirman Blok A No. 1,2 \& 3 Pematangsiantar \\ sumarno@amiktunasbangsa.ac.id ${ }^{1}$, jauhari.harahap@gmail.com²
}

\begin{abstract}
Abstrak
Kepolisian Negara Republik Indonesia atau yang sering disingkat dengan POLRI dalam kaitannya dengan Pemerintahan adalah salah satu fungsi pemerintahan negara di bidang pemeliharaan keamanan dan ketertiban masyarakat, penegakan hukum, perlindungan, pengayoman, dan pelayanan kepada masyarakat. Dengan berlakunya Undang-Undang Nomor 2 Tahun 2002 tentang Kepolisian maka jajaran kepolisian, semakin dituntut untuk mampu memberikan pelayanan yang sebaik-baiknya kepada masyarakat dan sekaligus mewujudkan ketentraman ditengah-tengah masyarakat. Dalam Undang-Undang ini secara jelas disebutkan mengenai tugas, fungsi dan wewenang sebagai polisi. Penelitian skripsi ini bertujuan untuk membuat sistem pendukung keputusan dalam memilih personil dikepolisian sebagai alat bantu bagi pimpinan dalam mengambil sebuah kebijakan. Dalam hal ini peneliti mengambil studi kasus di Polresta Simalungun di bagian Kepala Unit (Kanit) PPA. Data yang diperoleh berasal dari Polresta Simalungun dan kriteria yang dibuat berdasarkan keputusan kepala satuan reserse kriminal dengan 8 kriteria penilaian yakni pangkat, wawasan, tanggungjawab, sikap, kesatuan, kepedulian, paham UU dan kepemimpinan. Sampel data yang digunakan 3 alternatif untuk pemilihan di bagian Kepala Unit (Kanit) PPA tahun 2014. Dari sampel tersebut diperoleh nilai tertinggi 0,341 atas nama inisial Mr. B. Diharapkan dengan menggunakan salah satu metode dalam sistem pendukung keputusan, Proses perhitungan dengan menentukan kriteria yang telah ditentukan dapat memberikan output berupa rekomendasi kepala Kanit PPA menggunakan metode Weight Product.
\end{abstract}

Kata Kunci: Sistem Pendukung Keputusan (SPK), Weight Product, Kanit PPA, Polresta Simalungun

\begin{abstract}
The State Police of the Republic of Indonesia or often abbreviated with the Police in relation to the Government is one of the functions of state government in the field of maintaining security and public order, law enforcement, protection, advisory, and service to the public. With the enactment of Law No. 2 of 2002 on Police, the police force, the more demanded to be able to provide the best service to the community and at the same time realize the peace in the midst of society. The law clearly states the duty, function and authority of the police. This thesis research aims to make the decision support system in choosing personnel dikepolisian as a tool for the leadership in taking a policy. In this case the researcher took a case study at Polresta
\end{abstract}


simalungun in the Head Unit (Kanit) PPA. Data obtained from Polresta simalungun and criteria made based on the decision of head of criminal detective unit with 8 criteria of assessment that is panglat, insight, responsibility, attitude, unity, caring, understanding of Law and leadership. Samples of data used 3 alternatives for elections in the Head Unit (Kanit) PPA 2014. From the sample obtained the highest value 0.341 on behalf of initials Mr. B. Expected by using one of the methods in the decision support system, the calculation process by determining the predetermined criteria can provide output in the form of recommendation head of Kanit PPA using weight product method.

Keywords: Decision Support System (SPK), Weight Product, Kanit PPA, Simalungun Police

\section{PENDAHULUAN}

Kepolisian Negara Republik Indonesia atau yang sering disingkat dengan Polri dalam kaitannya dengan Pemerintahan adalah salah satu fungsi pemerintahan negara di bidang pemeliharaan keamanan dan ketertiban masyarakat, penegakan hukum, perlindungan, pengayoman, dan pelayanan kepada masyarakat, yang bertujuan untuk mewujudkan keamanan dalam negeri yang meliputi terpeliharanya keamanan dan ketertiban masyarakat, tertib dan tegaknya hukum, terselenggranya perlindungan, pengayoman, dan pelayanan kepada masyarakat, serta terbinanya ketentraman masyarakat dengan menjunjung tinggi hak azasi manusia.

Dalam menjalankan tugasnya, polisi pada dasarnya akan diperhadapkan dengan masyarakat. Disinilah akan tergambar dengan jelas bagaimana tugas polisi yang sesungguhnya sebagai pengayom masyarakat. Tentunya hal ini adalah tanggung jawab yang besar bagi seorang polisi untuk mendapatkan kepercayaan dari masyarakat terhadap pelayanan yang mereka lakukan. Disatu sisi, polisi juga adalah sebagai penegak hukum. Maka tanggung jawab seorang polisi tidaklah berhenti sebagai pengayom masyarakat tetapi juga tanggung jawabnya dalam menegakkan keadilan, dan masih banyak tanggung jawab lainnya.

Disamping itu, masyarakat masih sangat mengharapkan peningkatan peran dan tugas polisi sebagai pengayom, pelindung dan pelayanan masyarakat serta sebagai penegak hukum yang bersih. Dengan berlakunya Undang-Undang Nomor 2 Tahun 2002 tentang Kepolisian maka jajaran kepolisian, semakin dituntut untuk mampu memberikan pelayanan yang sebaik-baiknya kepada masyarakat dan sekaligus mewujudkan ketentraman ditengah-tengah masyarakat. Dalam Undang-Undang ini secara jelas disebutkan mengenai tugas, fungsi dan wewenang sebagai polisi. Namun, melihat pengaturan dalam Undang-Undang ini kemudian dikaitkan dengan aplikasinya dimasyarakat kemudian timbul pertanyaan bahwa Apakah kedudukan, fungsi, tugas, dan wewenang Polri sebagaimana yang telah diakomodir dalam UU Nomor 2 Tahun 2002 telah terlaksana dengan baik atau tidak?

Dalam hal ini sebuah sistem pendukung keputusan dibutuhkan dalam memilih personil dikepolisian sebagai alat bantu bagi pimpinan dalam mengambil sebuah kebijakan. Dalam hal ini peneliti mengambil studi kasus di Polresta Simalungun di bagian Kepala Unit (Kanit) PPA.

\section{METODE PENELITIAN}

\section{Sistem Pendukung Keputusan}

Sistem Pendukung Keputusan (SPK) sebagai sistem berbasis komputer yang terdiri dari tiga komponen yang saling berinteraksi, sistem bahasa (mekanisme untuk memberikan komunikasi antara pengguna dan komponen Sistem Pendukung Keputusan lain), sistem pengetahuan (repositori pengetahuan domain masalah yang ada pada Sistem Pendukung Keputusan atau sebagai data atau sebagai prosedur), dan sistem pemrosesan masalah (hubungan antara dua komponen lainnya, terdiri dari satu atau lebih kapabilitas manipulasi masalah umum yang diperlukan untuk pengambilan keputusan) (Nofriansyah, 2014).

Sistem Pendukung Keputusan adalah sistem informasi interaktif yang menyediakan informasi, pemodelan dan manipulasi data 
yang digunakan untuk membantu pengambil keputusan pada situasi semi terstruktur dan tak seorangpun tahu secara pasti bagaimana keputusan seharusnya dibuat (Fithri \& Latifah, 2010)

Sistem Pendukung Keputusan adalah suatu sistem informasi berbasis komputer yang menghasilkan berbagai alternatif keputusan untuk membantu manajemen dalam menangani berbagai permasalahan yang terstruktur dengan menggunakan data dan model (Faqih \& Irigasi, 2014).

\section{Karakteristik Sistem Pendukung Keputusan \\ Karakteristik dari sistem pendukung} keputusan adalah sebagai berikut:

1. Mendukung pengambilan keputusan untuk membahas masalah-masalah terstruktur, semi struktur, dan tidak terstruktur.

2. Output ditujukan bagi personil organisasi dalam semua tingkatan.

3. Mendukung di semua fase proses pengambilan keputusan: intelegensi, desain, pilihan.

4. Adanya interface manusia atau mesin, dimana manusia (user) tetap mengontrol proses pengambilan keputusan.

5. Menggunakan model-model metematis dan statistik yang sesuai dengan pembahasan.

6. Memiliki kemampuan dialog untuk memperoleh informasi sesuai dengan kebutuhan.

7. Memiliki subsistem-subsistem yang terintegrasi sedemikian rupa sehingga dapat berfungsi sebagai kesatuan sistem.

8. Membutuhkan struktur data komprehensif yang dapat melayani kebutuhan informasi seluruh tingkatan manajemen.

9. Pendekatan easy to use. Ciri suatu sistem pendukung keputusan yang efektif adalah kemudahannya untuk digunakan dan memungkinkan keleluasaan pemakai untuk memilih atau mengembangkan pendekatanpendekatan baru dalam membahas masalah yang dihadapi.

10. Kemampuan sistem untuk beradaptasi secara cepat, dimana pengambil keputusan dapat menghadapi masalah-masalah baru dan pada saat yang sama dapat menanganinya dengan cara mengadaptasikan sistem terhadap kondisi-kondisi perubahan yang terjadi (Nugraha, Surarso, \& Noranita, 2012).

Tahap-Tahap Pengambilan Keputusan

Tahap-tahap Pengambilan Keputusan yaitu:

a. Identifikasi masalah

b. Pemilihan metode

c. Pengumpulan data yang dibutuhkan untuk melaksanakan model keputusan tersebut.

d. Mengimplementasikan model tersebut

e. Mengevaluasi sisi positif dari setiap alternatif yang ada

f. Melaksanakan solusi terpilih (Siregar, 2015).

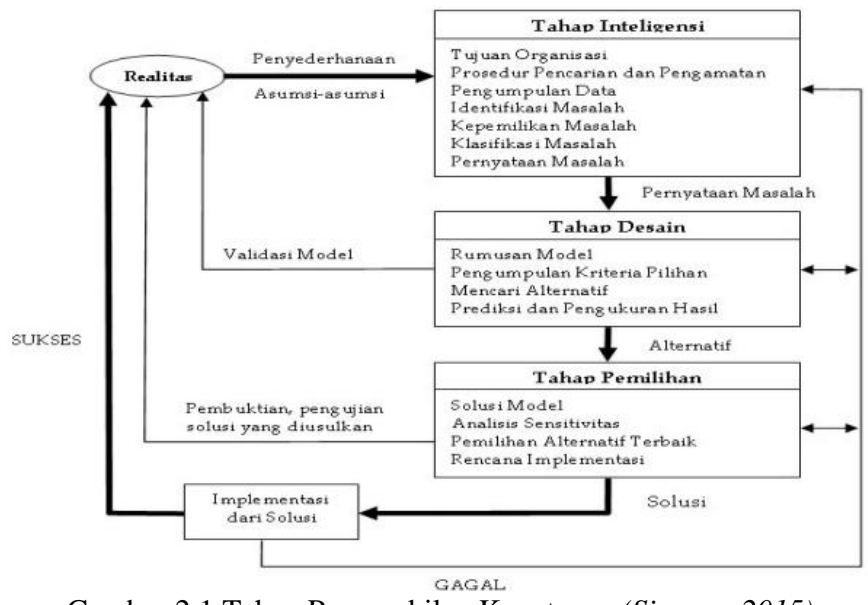

Gambar 2.1 Tahap Pengambilan Keputusan (Siregar, 2015) 


\section{Tahap Inteligence}

Suatu tahap proses seseorang dalam rangka pengambil keputusan untuk permasalahan yang dihadapi, terdiri dari aktivitas penelusuran, pendeteksian serta proses pengenalan masalah. Data masukan diperoleh, diuji dalam rangka mengidentifikasi masalah.

\section{Tahap Design}

Tahap proses pengambil keputusan setelah tahap intellegence meliputi proses untuk mengerti masalah, menurunkan solusi dan menguji kelayakan solusi. Aktivitas yang biasanya dilakukan seperti menemukan, mengembangkan dan menganalisa alternatif tindakan yang dapat dilakukan.

3. Tahap Pemilihan

Pada tahap ini dilakukan proses pemilihan diantara berbagai alternatif tindakan yang mungkin dijalankan. Hasil pemilihan tersebut kemudian diimplementasikan dalam proses pengambilan keputusan (Siregar, 2015).

\section{Weighted Product (WP)}

Metode WPM menggunakan perkalian untuk menghubungkan rating atribut, dimana rating setiap atribut harus dipangkatkan dulu dengan bobot atribut yang bersangkutan. Prosesini sama halnya dengan proses normalisasi. Preferensi untuk alternatif Ai (Lestari, 2013):

Weighted Product (WP) Metode weighted product merupakan metode untuk menyelesaikan Multi Attribute Decision Making (MADM). Weighted Product menggunakan teknik perkalian untuk menghubungkan rating attribute, dimana rating tiap atribut harus dipangkatkan terlebih dahulu dengan atribut bobot yang bersangkutan. Langkah-langkah yang dilakukan dalam penyelesaian masalah menggunakan metode Weighted Product adalah :

$$
S_{i}=\prod_{j=1}^{n} x_{i j}{ }^{w_{j}}
$$

$\mathrm{S}=$ Preferensi alternatif dianalogikan sebagai vektor $\mathrm{S}$

$\mathrm{Xij}=$ Nilai variabel dari alternatif pada setiap atribut

$$
\begin{array}{ll}
\mathrm{Wj} & =\text { Nilai bobot kriteria } \\
\mathrm{N} & =\text { Banyaknya kriteria } \\
\mathrm{I} & =\text { Nilai alternatif } \\
\mathrm{J} & =\text { Nilai kriteria }
\end{array}
$$

dimana $\sum \mathrm{Wj}=1 . \mathrm{Wj}$ adalah pangkat bernilai positif untuk atribut keuntungan, dan bernilai negatif untuk atribut biaya. Preferensi relatif dari setiap alternatif, diberikan sebagai

$$
V_{i}=\frac{\prod_{j=1}^{n} X_{i j}{ }^{w j}}{\prod_{j=1}^{n}\left(X_{j}^{*}\right)}
$$

V : Preferensi alternative dianologikan sebagai vector $\mathrm{V}$

$$
\begin{array}{ll}
\mathrm{X} & \text { : Nilai Kriteria } \\
\mathrm{W} & \text { : Bobot Kriteria / Sub kriteria } \\
\mathrm{i} & \text { : Alternatif } \\
\mathrm{j} & \text { : Kriteria } \\
\mathrm{n} & \text { : Banyaknya kriteria (Khairina, } \\
\text { Ivando, \& Maharani , 2016) }
\end{array}
$$

\section{Langkah-langkah Perhitungan Dengan Metode WP}

Langkah - langkah dalam perhitungan metode Weighted Product adalah sebagai berikut :

1. Menentukan kriteria-kriteria yang akan dijadikan acuan dalam pengambilan keputusan, yaitu $\mathrm{Ci}$

2. Menentukan rating kecocokan setiap alternatif pada setiap kriteria.

3. Membagi nilai $\mathrm{V}$ bagi setiap alternatif dengan nilai pada setiap alternatif

4. Ditemukan urutan alternatif terbaik yang akan menjadi keputusan (Nofriansyah, 2014)

\section{HASIL DAN PEMBAHASAN}

\section{Perhitungan Manual Weight Product (WP)}

Untuk proses perhitungan metode Weight Product, dapat dilihat pada tabel 3.1. dibawah ini

Keterangan : 
Tabel 3.1. Proses perhitungan metode Weight Product

\begin{tabular}{|l|l|}
\hline Name & $\begin{array}{l}\text { Proses perhitungan dengan } \\
\text { metode Weight Product }\end{array}$ \\
\hline Actors & Admin yang telah ditentukan \\
\hline Description & $\begin{array}{l}\text { Use case ini mendeskripsikan } \\
\text { proses perhitungan dalam } \\
\text { penentuan pemilihan Kepala Unit } \\
\text { (Kanit) PPA dengan metode } \\
\text { Weight Product }\end{array}$ \\
\hline Basic Flow & $\begin{array}{l}\text { Admin menginput data kriteria } \\
\text { Calon Kepala Unit (Kanit) PPA }\end{array}$ \\
\hline Alternate Flow & $\begin{array}{l}\text { Admin bisa melihat data kriteria } \\
\text { yang dinputkan }\end{array}$ \\
\hline Pre Condition & $\begin{array}{l}\text { Admin dapat melihat hasil } \\
\text { running time dari hasil } \\
\text { perhitungan }\end{array}$ \\
\hline Post Condition & $\begin{array}{l}\text { Admin dapat melihat data } \\
\text { pengujian didalam database }\end{array}$ \\
\hline
\end{tabular}

Dalam penentuan pemilihan Kepala Unit (Kanit) PPA, terdapat beberapa kriteria yang bisa menjadi acuan sebagai bahan pertimbangan penyeleksian. Dalam hal ini akan diperlihatkan bagaimana hasil perhitungan manual dengan menggunakan algoritma Weight Product (WP) yang dilakukan dengan mengambil sampel 5 (lima) data siswa kursus untuk tingkatan Pre Primary. Hasil ini nantinya akan dibandingakan dengan output dengan menggunakan sistem. Untuk mendapatkan hasilnya, terlebih dahulu dilakukan perbaikan bobot, perbaikan bobot menggunakan rumus $W_{j}$. Sebelum melakukan perhitungan perbaikan bobot, data input yang digunakan adalah data sampel pemilihan Kepala Unit (Kanit) PPA tahun 2014. Maka dapat dihitung sebagai berikut:

a. Data sampel calon Kepala Unit (Kanit) PPA tahun 2014

Dari tabel 3.1 diatas, proses penilaian terhadap pemilihan Kepala Unit (Kanit) PPA dilakukan oleh Ajudan Komisaris Polisi dengan mengacu kepada Lampiran SRT Peraturan Kapolri No. 23/VI/2010 Tanggal 30 November 2010. Adapun lampiran kriteria dapat dilihat pada gambar 3.1 dibawah ini :

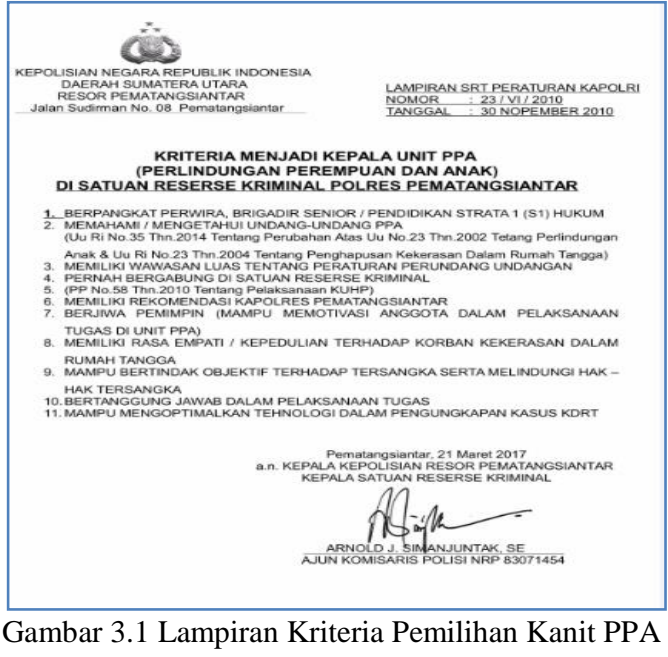

Adapun kriteria menggunakan nilai Crips dimana penilaian dilakukan langsung oleh Ajudan Komisaris Polisi. Penilaian ini diubah kebilangan Crips agar dapat dilakukan proses perhitungan dengan menggunakan metode weight product. Adapun daftar konversi bilangan crips untuk kriteria Wawasan, Tanggungjawab, Sikap, Kepedulian dan Kepemimpinan dapat dilihat pada tabel 3.2. berikut:

Tabel 3.2. Konversi bilangan Crips

\begin{tabular}{|l|l|}
\hline Keterangan (Kategori) & Nilai Crips \\
\hline Sangat Baik (SB) & $91-100$ \\
\hline Baik (B) & $81-90$ \\
\hline Cukup (C) & $61-80$ \\
\hline Kurang (K) & $<60$ \\
\hline
\end{tabular}

Dari konversi nilai yang dilakukan dengan menggunakan acuan tabel 3.2, maka diperoleh hasil tabel konversi. Untuk kriteria Pangkat, Kesatuan dan Pahan $\boldsymbol{U} U$ dapat dilihat pada tabel berikut:

Tabel 3.3. Nilai Kriteria Pangkat

\begin{tabular}{|l|l|l|}
\hline $\begin{array}{l}\text { Keterangan } \\
\text { (Kategori) }\end{array}$ & Keterangan & $\begin{array}{l}\text { Nilai } \\
\text { Crips }\end{array}$ \\
\hline Perwira Menengah & $\begin{array}{l}\text { Kombes Pol, AKBP } \\
\text { dan Kompol }\end{array}$ & 4 \\
\hline Perwira Pertama & AKP, Iptu dan Ipda & 3 \\
\hline Bintara Tinggi & Aiptu dan Aipda & 2 \\
\hline
\end{tabular}

Tabel 3.4. Nilai Kriteria Kesatuan

\begin{tabular}{|l|c|}
\hline Keterangan (Kategori) & Nilai Crips \\
\hline Reserse & 4 \\
\hline Satlantas & 3 \\
\hline Lainnya & 2 \\
\hline
\end{tabular}

Tabel 3.5. Nilai Kriteria Paham UU

\begin{tabular}{|l|l|}
\hline Keterangan (Kategori) & Nilai Crips \\
\hline Sangat Menguasai & 4 \\
\hline Menguasai & 3 \\
\hline Kurang Menguasai & 2 \\
\hline
\end{tabular}


Tabel 3.6. Data olahan \& Data Konversi

\begin{tabular}{|c|c|c|c|}
\hline $\begin{array}{c}\text { Calon } \\
\text { Kepala } \\
\text { Unit } \\
\text { (Kanit) } \\
\text { PPA }\end{array}$ & $\begin{array}{c}\text { Pangkat } \\
\text { (C1) }\end{array}$ & $\begin{array}{c}\text { Wawasan } \\
\text { (C2) }\end{array}$ & $\begin{array}{c}\text { Tanggung } \\
\text { jawab (C3) }\end{array}$ \\
\hline Mr.A & Ipda & 75 & 83 \\
\hline Mr.B & Ipda & 87 & 89 \\
\hline Mr.C & Ipda & 97 & 70 \\
\hline
\end{tabular}

\begin{tabular}{|c|c|c|c|c|}
\hline $\begin{array}{c}\text { Sikap } \\
(\mathrm{C} 4)\end{array}$ & $\begin{array}{c}\text { Kesatua } \\
\mathrm{n}(\mathrm{C} 5)\end{array}$ & $\begin{array}{c}\text { Keped } \\
\text { ulian } \\
(\mathrm{C} 6)\end{array}$ & $\begin{array}{c}\text { Paham UU } \\
(\mathrm{C} 7)\end{array}$ & $\begin{array}{c}\text { Kepe } \\
\text { mim } \\
\text { pinan } \\
(\mathrm{C} 8)\end{array}$ \\
\hline 76 & $\begin{array}{c}\text { Reserse } \\
\text { Krimina } \\
1\end{array}$ & 87 & Menguasai & 83 \\
\hline 72 & $\begin{array}{c}\text { Reserse } \\
\text { Krimina } \\
1\end{array}$ & 95 & $\begin{array}{c}\text { Sangat } \\
\text { Menguasai }\end{array}$ & 75 \\
\hline 65 & $\begin{array}{c}\text { Reserse } \\
\text { Krimina } \\
1\end{array}$ & 88 & $\begin{array}{c}\text { Sangat } \\
\text { Menguasai }\end{array}$ & 90 \\
\hline
\end{tabular}

\begin{tabular}{|l|c|c|c|c|c|c|c|c|}
\hline $\begin{array}{c}\text { Calon } \\
\text { Kepala } \\
\text { Unit } \\
\text { (Kanit) } \\
\text { PPA }\end{array}$ & $\mathrm{C}$ & $\mathrm{C}$ & $\mathrm{C}$ & $\mathrm{C}$ & $\mathrm{C}$ & $\mathrm{C}$ & $\mathrm{C}$ & $\mathrm{C}$ \\
\hline Mr.A & 3 & 75 & $\begin{array}{c}8 \\
3\end{array}$ & 76 & 4 & 87 & 3 & 83 \\
\hline Mr.B & 3 & 87 & $\begin{array}{c}8 \\
9\end{array}$ & 72 & 4 & 95 & 4 & 75 \\
\hline Mr.C & 3 & 97 & $\begin{array}{c}7 \\
0\end{array}$ & 65 & 4 & 88 & 4 & 90 \\
\hline
\end{tabular}

b. Kriteria penilaian yang digunakan sebagai acuan adalah :

Tabel 3.7. Daftar kriteria penilaian

\begin{tabular}{|c|l|l|l|}
\hline No & Nama Kriteria & Inisial & Kepentingan \\
\hline 1 & Pangkat & C1 & Benefit \\
\hline 2 & Wawasan & C2 & Benefit \\
\hline 3 & Tanggungjawab & C3 & Benefit \\
\hline 4 & Sikap & C4 & Benefit \\
\hline 5 & Kesatuan & C5 & Benefit \\
\hline 6 & Kepedulian & C6 & Benefit \\
\hline 7 & Paham UU & C7 & Benefit \\
\hline 8 & Kepemimpinan & C8 & Benefit \\
\hline
\end{tabular}

c. Menentukan tingkat ketergantungan / kepentingan setiap kriteria (bobot).

Dalam menentukan bobot setiap kriteria, hal ini dilakukan oleh pihak pengambil keputusan. Bobot ini berupa lingustik yang terdiri dari Sangat Rendah, Rendah, Cukup, Tinggi dan Sangat Tinggi. Bobot tersebut diterjemahkan dengan nilai crips untuk membantu perhitungan algoritma :

$$
1 \text { = Sangat Rendah, }
$$

2 = Rendah,

3 = Cukup,

4 = Tinggi,

5 = Sangat Tinggi.

Tabel 3.8. Daftar kriteria penilaian yang sudah diberikan bobot

\begin{tabular}{|c|l|l|l|l|}
\hline $\begin{array}{l}\text { N } \\
\text { o }\end{array}$ & $\begin{array}{l}\text { Kama } \\
\text { Kriteria }\end{array}$ & Inisial & Bobot & Keterangan \\
\hline 1 & Pangkat & C1 & 5 & $\begin{array}{l}\text { Sangat } \\
\text { Tinggi }\end{array}$ \\
\hline 2 & Wawasan & C2 & 5 & $\begin{array}{l}\text { Sangat } \\
\text { Tinggi }\end{array}$ \\
\hline 3 & $\begin{array}{l}\text { Tanggungja } \\
\text { wab }\end{array}$ & C3 & 5 & $\begin{array}{l}\text { Sangat } \\
\text { Tinggi }\end{array}$ \\
\hline 4 & Sikap & C4 & 4 & Tinggi \\
\hline 5 & Kesatuan & C5 & 3 & Cukup \\
\hline 6 & Kepedulian & C6 & 4 & Tinggi \\
\hline 7 & Paham UU & C7 & 5 & $\begin{array}{l}\text { Sangat } \\
\text { Tinggi }\end{array}$ \\
\hline 8 & $\begin{array}{l}\text { Kepemimpi } \\
\text { nan }\end{array}$ & C8 & 5 & $\begin{array}{l}\text { Sangat } \\
\text { Tinggi }\end{array}$ \\
\hline
\end{tabular}

d. Pengambilan keputusan memberikan bobot referensi sebagai berikut :

$\mathrm{W}=(5+5+5+4+3+4+5+5)=36$

e. Sebelumnya dilakukan perbaikan bobot terlebih dahulu maka pangkat diperoleh dari jumlah w dibagi masing - masing nilai dari kriteria yang sudah ditentukan, dan hasilnya adalah :

$$
\begin{aligned}
& W 1=\frac{5}{(5+5+5+4+3+4+5+5)} \\
& =0,1389 \\
& W 2=\frac{4}{(5+5+5+4+3+4+5+5)} \\
& =0,1389 \\
& W 3=\frac{5}{(5+5+5+4+3+4+5+5)} \\
& W 4=\frac{1389}{(5+5+5+4+3+4+5+5)} \\
& W 5=\frac{4}{(5+5+5+4+3+4+5+5)} \\
& =0,0833 \\
& W 6=\frac{4}{(5+5+5+4+3+4+5+5)} \\
& =0,1111 \\
& W 7=\frac{5}{(5+5+5+4+3+4+5+5)} \\
& =0,1389
\end{aligned}
$$




$$
\begin{gathered}
W 8=\frac{5}{(5+5+5+4+3+4+5+5)} \\
=0,1389
\end{gathered}
$$

Tabel 3.9. Tabel perbaikan bobot kriteria

\begin{tabular}{|c|l|c|c|}
\hline No & \multicolumn{1}{|c|}{ Kriteria } & Bobot & $\begin{array}{c}\text { Perbaikan } \\
\text { Bobot }\end{array}$ \\
\hline 1 & Pangkat & 5 & 0,1389 \\
\hline 2 & Wawasan & 5 & 0,1389 \\
\hline 3 & Tanggungjawab & 5 & 0,1389 \\
\hline 4 & Sikap & 4 & 0,1111 \\
\hline 5 & Kesatuan & 3 & 0,0833 \\
\hline 6 & Kepedulian & 4 & 0,1111 \\
\hline 7 & Paham UU & 5 & 0,1389 \\
\hline 8 & Kepemimpinan & 5 & 0,1389 \\
\hline
\end{tabular}

Kemudian langkah selanjutnya adalah menghitung vector S, dimana data - data akan dikalikan, tetapi sebelumnya dilakukan pemangkatan dengan bobot perubahan yang ada pada tabel 3.8 :

\section{S1(Mr.A)}

$$
\begin{aligned}
=\left(3^{0.1389}\right)+ & \left(75^{0.1389}\right)+\left(83^{0.1389}\right) \\
& +\left(76^{0.1111}\right)+\left(4^{0.0833}\right) \\
& +\left(87^{0.1111}\right)+\left(3^{0.1389}\right) \\
& +\left(83^{0.1389}\right)=25,1588
\end{aligned}
$$

2. $\mathrm{S} 2(\mathrm{Mr} . \mathrm{B})$

$$
\begin{aligned}
=\left(3^{0.1389}\right)+ & \left(87^{0.1389}\right)+\left(89^{0.1389}\right) \\
& +\left(72^{0.1111}\right)+\left(4^{0.0833}\right) \\
& +\left(95^{0.1111}\right)+\left(4^{0.1389}\right) \\
& +\left(75^{0.1389}\right)=26,7133
\end{aligned}
$$$$
\text { 3. S3(Mr.C) }
$$

$$
\begin{aligned}
=\left(3^{0.1389}\right)+ & \left(97^{0.1389}\right)+\left(70^{0.1389}\right) \\
& +\left(65^{0.1111}\right)+\left(4^{0.0833}\right) \\
& +\left(88^{0.1111}\right)+\left(3^{0.1389}\right) \\
& +\left(90^{0.1389}\right)=26,3738
\end{aligned}
$$

Setelah nilai vector $\mathrm{S}$ didapat, maka selanjutnya adalah menjumlahkan seluruh $\mathrm{S}$ untuk menghitung $\mathrm{V}$. Perhitungannya sebagai berikut :

$$
\begin{gathered}
V 1 \\
=\frac{25,1588}{25,1588+26,7133+26,3738} \\
=0,322 \\
\begin{array}{c}
26,7133 \\
=0,341
\end{array}
\end{gathered}
$$

$$
V 3=\frac{26,3738}{25,1588+26,7133+26,3738}=
$$

Maka dari perhitungan diatas dapat diperoleh nilai terbesar terdapat pada Mr.B. Untuk lebih jelas perhatikan tabel 3,10 berikut

Tabel 3.10. Hasil akhir perhitungan Weight Product (WP)

\begin{tabular}{|c|l|c|c|c|}
\hline No & $\begin{array}{l}\text { Nama Calon } \\
\text { Kanit PPA }\end{array}$ & Nilai & Rank & Hasil \\
\hline 1 & Mr.A & 0,322 & 3 & Gagal \\
\hline 2 & Mr.B & 0,341 & 1 & Lulus \\
\hline 3 & Mr.C & 0,337 & 2 & Gagal \\
\hline
\end{tabular}

\section{Flowchart}

Flowchart adalah penggambaran secara grafik dalam bentuk diagram alir dari suatu algoritma dalam suatu program yang menyatakan arah alur program dalam menyelesaikan suatu masalah.

Untuk membangun sistem pendukung keputusan untuk menentukan pemilihan Kepala Unit (Kanit) PPA dengan metode Weight Product dapat dilihat seperti pada Gambar 3.7

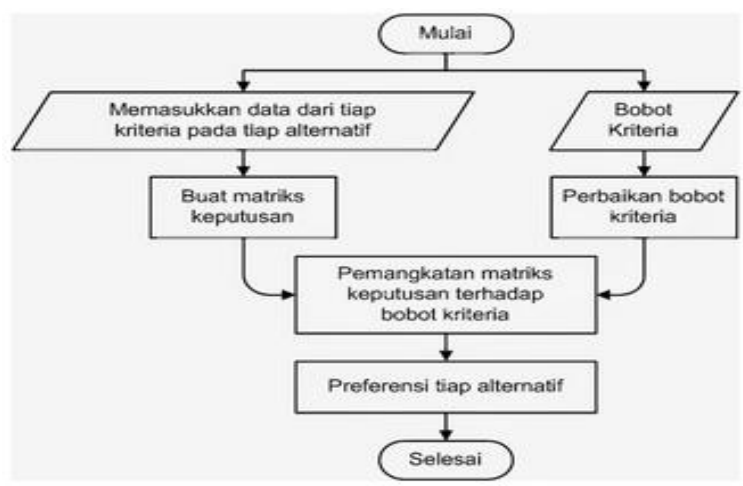

Gambar 3.7. Flowchart Metode Weight Product

\section{KESIMPULAN}

Berdasarkan dari hasil implementasi dan pengujian sistem pendukung keputusan pemilihan Kanit PPA di Polresta Pematangsiantar dengan metode Weight Product, dapat disimpulkan bahwa :

1. Sistem dapat menyelesaikan permasalahan dengan mengimplementasikan metode Weight 
Product.

2. Dari hasil pengujian sistem, metode Weight Product, menghasilkan alternaif yang sama dengan perhitungan manual yang dilakukan.

4. Dari hasil pengujian, metode Weighted Product dapat lebih cepat memperoses data dibandingkan dengan pengambilan keputusan yang dilakukan dengan cara tradisional.

5. Sistem akan mengeluarkan output yang dapat membantu pengambil keputusan dalam menentukan Pemilihan Posisi Kepala Unit (Kanit) PPA dengan Metode Weight Product (WP)

\section{DAFTAR PUSTAKA}

Faqih, H., \& Irigasi, J. (2014). Implementasi dss dengan metode saw untuk menentukan prioritas pekerjaan operasi dan pemeliharaan sistem irigasi dpu kabupaten tegal. Jurnal Bianglala Informatika, 19-32.

Fithri, D. L., \& Latifah, N. (2010). Sistem Pendukung Keputusan Untuk Pemberian Bantuan Usaha Mikro Dengan Metode Simple Additive Weighting. Majalah Ilmiah Informatika, 3(2), 117-129.

Khairina, D. M., Ivando, D., \& Maharani , S. (2016). Implementasi Metode
Wighted Product Untuk Aplikasi Pemilihan Smartphone Android . Jurnal Infotel, 1-8.

Lestari, S. (2013). Penerapan Weighted Product Model Untuk Seleksi Calon Karyawan. Jurnal Sistem Informasi, 540-545.

Nofriansyah, D. (2014). Konsep Data Mining vs Sistem Pendukung Keputusan Edisi 1. Yogyakarta: Deepublish.

Nugraha, F., Surarso, B., \& Noranita, B. (2012). Sistem Pendukung Keputusan Evaluasi Pemilihan Pemenang Pengadaan Aset dengan Metode Simple Additive Weighting (SAW). Jurnal Sistem Informasi Bisnis, 67-72.

Siregar, M. (2015). Sistem Pendukung Keputusan Pemilihan Guru Teladan di SMA Era Utama Pancur Batu. Pelita Informatika : Informasi dan Informatika, 76-84. 